
http://www.anpad.org.br/bar

\title{
Antecedents and Consequences of Consumer Trust in the Context of Service Recovery
}

\author{
Cristiane Pizzutti dos Santos * \\ E-mail address: cpsantos@ea.ufrgs.br \\ Universidade Federal do Rio Grande do Sul \\ Porto Alegre, RS, Brazil.
}

\section{Daniel Von der Heyde Fernandes \\ E-mail address: dvon@ @erra.com.br \\ Universidade Federal do Rio Grande do Sul \\ Porto Alegre, RS, Brazil.}

\begin{abstract}
The purpose of this paper is to investigate the antecedents and consequences of consumer trust after complaint handling episodes about services. A cross-sectional study was carried out with complainers of banks and airline companies. The respondents were approached at an International Airport in Brazil. Structural Equation Modeling was used to test the hypotheses developed. The building of consumer trust was sensitive to perceptions of justice regarding the way complaints were handled by the company. More specifically, the perception of interactional fairness strongly impacted consumer trust in the employees which, in turn, revealed a high impact on trust in the company. Insofar as satisfaction with complaint handling does not mediate the relationship between the dimensions of fairness and trust, following a conflict it loses part of its importance. Finally, both repurchase intention and word-of-mouth communication were influenced by trust in the company, satisfaction with complaint handling and perceived value. The company should attentively observe the interactional aspect in terms of developing relationships with customers. Appropriate complaint handling and the consequent trust created between the parties is an efficient form of developing and maintaining solid relationships with customers.
\end{abstract}

Key words: service recovery; complaint management; fairness; trust; loyalty.

Received 14 November 2007; received in revised form 01 July 2008.

Copyright (c) 2008 Brazilian Administration Review. All rights reserved, including rights for translation. Parts of this work may be quoted without prior knowledge on the condition that the source is identified.

*Corresponding author: Cristiane Pizzutti dos Santos

Rua Washington Luis, 855, Centro, Porto Alegre, RS, 90010-460, Brazil. 


\section{INTRODUCTION}

Researchers and practitioners have witnessed a gradual paradigm shift in the area of marketing that essentially emphasizes the retention of current customers, rather than the pursuit of new customers or the focus on singular exchanges. In this context, the critical role of trust in promoting loyalty and more relational exchanges has been emphasized (Berry, 1996; Ganesan, 1994; Nooteboom, Berger, \& Nooderhaven, 1997). Berry (1996) even claims that "the inherent nature of services, coupled with abundant mistrust in U.S. society, positions trust as perhaps the single most powerful relationship marketing tool available to a company" (p. 242). Feelings of trust offer a "pledge" that the performance of the company will be consistent and competent, which in turn means that the consumer will continue to gain value from future service encounters with the same provider. Reducing risk in business exchanges, trust contributes to giving continuity to the relationship and to creating feelings of loyalty.

The emergence of conflicts between consumers and companies and their management, inherent to longstanding relationships, leads to, for the most part, the maintenance or the breakdown of consumer trust in the company. Conflict situations, particularly regarding complaint episodes, seem to be critical to trust because there is the perception that it is in adversity that partners are put to the test.

Based on this scenario, the core objective of this paper is to investigate the antecedents and consequences of consumer trust after situations of complaint handling. Accordingly, a theoretical model will be tested, based essentially on the literature on the theory of fairness applied to the context of service recovery, trust and loyalty. In this model, three dimensions of fairness - distributive, procedural and interactional - act as independent variables that help assess the complaint process, and influence post-complaint satisfaction and consumer trust. Trust, in turn, together with the perceived value and satisfaction, will affect consumer loyalty.

This article expands on existing knowledge concerning consumer trust, by: a) considering it under two dimensions - trust in employees and in company policies, b) approaching it after a situation of conflict resolution, c) assessing the direct impact of perceptions of fairness on consumer trust, and not only through satisfaction with service recovery, d) examining the influence of trust on loyalty, considering two dimensions - positive word-of-mouth and repurchase intention, e) investigating the antecedents and consequences of trust in the same theoretical structure, f) focusing the study on more relational-oriented exchanges.

This article consists of three main parts. The first deals with the theoretical foundation underpinning this study, emphasizing the literature on consumer trust and the theoretical framework to be tested. The second part discusses the aspects pertaining to the research method, and the third presents the principal findings.

\section{THEORETICAL FOUNDATION AND RESEARCH HYPOTHESES}

This section develops a set of hypotheses that describe how service failure and recovery encounters influence customer's trust, repatronage and word-of-mouth intentions.

\section{Consumer Trust}

Trust is a concept studied in various disciplines and, as a result, there are different definitions of trust. Usually, trust is seen as an expression of security between partners when making an exchange, or in another type of relationship (Garbarino \& Johnson, 1999), as a belief that the partner in a negotiation will not exploit or take advantage of the other's vulnerability (Dwyer, Schurr, \& Oh, 1987) or as a willingness to rely on an exchange partner in whom one has confidence (Moorman, Deshpandé, 
\& Zaltman, 1993). Consumer trust is defined here as "the expectations held by the consumer that the service provider is dependable and can be relied on to deliver on its promises" (Sirdeshmukh, Singh, \& Sabol, 2002, p. 17).

Conceptual (Nooteboom et al., 1997) and empirical (Garbarino \& Johnson, 1999; Morgan \& Hunt, 1994; Tax, Brown, \& Chandrashekaran, 1998) studies have pointed to trust as a fundamental ingredient for the development of strong and long-term relationships between consumers and organizations. According to Singh and Sirdeshmukh (2000)

trust is not a necessary ingredient for consummating consumer-firm exchanges, just as the presence of distrust does not in and of itself preclude consummation. Rather, situations will vary by the degree to which they evoke the relevance of trust and trigger mechanisms that are affected by the level of trust (p. 154).

According to Rousseau, Sitkin, Burt and Camerer (1998), there is an agreement among researchers regarding the conditions in which trust becomes relevant. One such condition is the presence of risk, which refers to the perceived probability of loss. Uncertainty as to whether the other's actions will be appropriate or not represents a source of risk. Trust would help reduce uncertainty and risk in transactions. The second condition necessary for the emergence of trust is interdependence, where the interests and objectives of one party cannot be attained without trust in the other party.

Thus, it is perceived that the particular characteristics of service provision, such as intangibility and variability, contribute to the creation of a favorable environment for the relevance of constructs such as trust and loyalty and, consequently, for the establishment of more solid relationships between consumers and companies. In services marketing, Berry and Parasuraman (1991) report "customercompany (lasting) relationships require trust" (p. 144). Indeed, they contend, "Effective services marketing depends on the management of trust because the customer typically must buy a service before experiencing it" (p. 107).

Consumer trust in the service provider seems to be formed around two distinct facets - trust in the employees and trust in the firm (Sirdeshmukh et al., 2002). In most services, these facets are distinct nodes and the customer forms independent judgments during the course of a service encounter. These differences may occur because the inferential basis of evaluations is different; trust in the employees is formed by perceptions of the employees' behavior demonstrated during work sessions, whereas judgments regarding trust in the company are essentially based on the policies and practices governing the exchange. As a consequence, it is plausible that consumers hold different judgments about trust in relation to the employees and the company as a whole.

The inclusion of multiple facets in consumer evaluations of services has been supported by several authors (Crosby \& Stephens, 1987; Doney \& Cannon, 1997; Singh \& Sirdeshmukh, 2000). Crosby and Stephens (1987), for instance, have conceptualized consumers' overall satisfaction with a service as having three distinct dimensions, including satisfaction with: (1) the person with whom the first contact was made; (2) the core service; and (3) the organization. In the inter-organizational context, Doney and Cannon (1997) have offered evidence that the provider firm and the sales representative represent different facets of trust from the perspective of the purchasing firm. Sirdeshmukh et al. (2002) have validated this structure by means of two dimensions of trust through high rates of reliability and the adjustment of the measurement model, as well as the asymmetrical impact of these facets on consumer loyalty and perceived value.

\section{Trust Antecedents Following Post-service Recovery}

Previous studies have suggested that three variables for the formation of trust need to be considered. The first concerns the consumer's notion regarding the company's competence (Barclay \& Smith, 1997); the second is the perception of benevolence (Ganesan \& Hess, 1997); and the third is the consumer's evaluation of the company's orientation towards problem-solving (Sirdeshmukh et al., 2002). The consistent use of these dimensions, especially the first two, in the inter-organizational 
literature, as important antecedents of trust, has been demonstrated in a series of studies (Ganesan \& Hess, 1997; McAllister, 1995; Sirdeshmukh et al., 2002).

Nevertheless, in the context of service recovery it seems that variables specifically related to the complaint episode would influence the consumer's trust in a more direct, intense way. In the Brazilian context, the study by Santos and Rossi (2002) identified a model in which consumer evaluations of the complaint episodes were antecedents of trust as superior when compared to a rival model, which showed the dimensions of benevolence and competence as antecedents. Therefore, this study proposes the evaluation of complaint handling and the prior experiences with the company as antecedents of trust. In this respect, studies on the theory of complaint fairness and customer satisfaction are approached in order to explain the formation of consumer trust.

Contemporary studies on complaint handling have offered substantial evidence of the suitability of the concept of justice as a basis for understanding the process of service recovery and its outcomes (Blodgett, Hill, \& Tax, 1997; Goodwin \& Ross, 1992; Smith, Bolton, \& Wagner 1999; Tax et al., 1998). This concept involves three different dimensions. Following the chronological order in which they appear in the literature, the first dimension explored was distributive fairness, emphasized by the equity theory. Distributive justice is the allocation of benefits and costs between parties in a transaction. In the complaint context, distributions are seen as tangible outcomes offered by the company to the complainer (e.g., item replacement or refund).

The second dimension is Procedural Fairness. This dimension concerns the policies and procedures used by companies during complaint processes and includes six sub-dimensions: flexibility, accessibility, process control, decision control, response speed and acceptance of responsibility (Blodgett et al., 1997; Tax et al., 1998; Thibaut \& Walker, 1975).

The third dimension is Interactional Fairness, which involves the way employees treat and communicate with consumers during the complaint episode. Six sub-dimensions have been studied: courtesy, honesty, offering explanations, empathy, endeavor, and offering apologies (Clemmer, 1988; Tax et al., 1998).

According to the literature on social justice, satisfaction is linked to assessments of justice in various conflict situations (Messick \& Cook, 1983). Extending this logic to complaint handling, today it is widely accepted that consumer satisfaction with a complaint episode results from the evaluation of the aspects involving the final outcome, the process leading to this result and the way in which the consumer was approached and treated, i.e., how fair these aspects were (Blodgett et al., 1997; Goodwin \& Ross, 1992; Smith et al., 1999; Tax et al., 1998).

The magnitude of the effect of each one of these dimensions has been a matter of disagreement among researchers in the area. Tax et al. (1998) and Blodgett et al. (1997) found that the effect of interactional justice on satisfaction with complaint handling is, somehow or other, of a greater magnitude than the effect of distributive and procedural justices; whereas in the studies by Goodwin and Ross (1992), Smith et al. (1999) and Santos and Rossi (2002), distributive justice accounted for a relatively higher percentage of the total effect of the justice perceived in the satisfaction. Therefore, no hypothesis comparing the effects of the dimensions of fairness on satisfaction will be advanced.

Thus, it is proposed that each dimension of justice - distributive, procedural and interactional - will impact consumer evaluations regarding their satisfaction with the complaint resolution.

\section{$\mathrm{H}_{1}$ : Perceptions of Justice (a) interactional, (b) procedural and (c) distributive will have a positive impact on satisfaction with complaint handling.}

The role of satisfaction as a central element, linking consumer perceptions regarding service recovery with future attitudes and behavior, has been widely validated (Bitner, Booms, \& Tetreault, 1990; Dube \& Maute, 1998; Tax et al., 1998; Webster \& Sundaram, 1998). Post-purchase (or initial) satisfaction has been considered a central mediator, linking beliefs prior to purchase with postpurchase cognitive structures, communications and repurchase behavior (Westbrook, 1987). Similarly, satisfaction with complaint handling (or final) can be considered a key element, mediating the relation between the evaluations of this management and the attitudes and post-complaint behavior. However, 
the focus has mostly been on the immediate behavior intentions concerning the product or service in question (e.g., repurchase intentions), rather than on variables, such as trust, which reveal the potential for long-term relationships. The work of Tax et al. (1998) is one of the few to explore the relationship between satisfaction and relational variables. They found a significant, positive relationship between satisfaction and post-complaint trust, highlighting that satisfaction with conflict management plays a key role in promoting (or reducing) trust among the parties involved. Hence, there follows the group of hypotheses proposed in the present study:

$\mathrm{H}_{2}$ : Consumer satisfaction with complaint handling will positively impact consumer trust in the company.

$\mathrm{H}_{3}$ : Consumer satisfaction with complaint handling will positively impact consumer trust in employees.

In addition to the influence of satisfaction with complaint handling, it is proposed that a consumer's prior experiences with the company will have an impact on consumer trust because as trust is built, not on a single episode, but on good and successive experiences with the company, experiences prior to the episode originating the complaint are likely to significantly influence trust. Hence, it follows that:

\section{$\mathrm{H}_{4}$ : Prior experience with the company will positively impact consumer trust in the company.}

\section{$\mathrm{H}_{5}$ : Prior experience with the company will positively impact consumer trust in employees.}

In addition to the mediating role of satisfaction with complaint handling, linking justice evaluations to the consumer trust, it is believed that justice evaluations act directly on trust (in the employees and in the company). One of the few studies to explore the direct relationship between the dimensions of justice and customer trust is that of Ruyter and Wetzels (1999), who found a significant relationship. The basis for this relationship resides in the fact that a single failure in service provision is not likely to destroy consumer trust in the organization (Berry \& Leighton, 2004), but a recovery perceived as unfair by the customer means a double failure, and may have a significant reducing impact on trust. Following this reasoning, it is proposed that:

$\mathrm{H}_{6}$ : Perceptions of justice (a) interactional, (b) procedural and (c) distributive, will positively impact consumer trust in the company.

$\mathrm{H}_{7}$ : Perceptions of justice (a) interactional, (b) procedural and (c) distributive, will positively impact consumer trust in employees.

The exploratory nature of relationships between the dimensions of justice and the facets of trust impedes the elaboration of more specific hypotheses. According to Clemmer and Schneider (1996), "the concept of fairness provides a theoretical framework for the study of dissatisfied consumers' postcomplaint behaviors" (p. 111), but some main questions remain unexplored. The analysis herein intends to bring forth a more comprehensive understanding of the relationships between specific evaluations of the complaint episode and the consumer trust in the company and in its employees, to offer a foundation for further theorising and as so to provide impetus for future research.

\section{The Impact of Trust in Employees on Trust in the Company}

According to the study of Bergen, Dutta and Walker (1992), and research on the role of causal attribution in judgments (Folkes, 1988), consumer trust in employees will directly influence trust in the company. Bergen et al. (1992) applied the Agency Theory in marketing to stipulate that employees interact with the consumer as the company's agents, acting under the guidelines established by the company. Thus, the greater the trust in the employees, the greater the trust in the company, which apparently controls and determines the agent's behavior. Similarly, attributions theory proposes that consumers attribute trust in employees in part to the company having hired, trained and acculturated the employee, among other management practices (Heskett, Sasser, \& Schlesinger, 1997). Therefore, by attributing the source and the control of the causes underlying employee behavior to the company, trust in employees may influence trust in the company. Empirical support is provided by a review of 
the literature on services (Bitner et al., 1990; Crosby \& Stephen, 1987). For instance, Crosby and Stephen (1987) demonstrate that satisfaction with the employees contributes to increasing satisfaction with the service as a whole, and the study by Sirdeshmukh et al. (2002) found, in relational exchanges, a strong impact of the consumer's trust in employees on the consumer's trust in the company.

The literature also offers support for the reciprocal relationship such as consumers' trust in the company is likely to enhance trust in the employees. Doney and Cannon (1997) argue that when customers have a limited knowledge of the employees, trust in the company exerts a direct impact on trust in employees. Nevertheless, as in the present study consumers were asked to evaluate service providers with whom they had already had prior experience, and, therefore, were familiar with the company and its employees, we expected that no effects in that way - trust in the company to trust in employees - would be measurable in the strict context of this research. Therefore, in our study, trust in the company should not exert a strong impact on trust in employees; the inverse situation, however, should occur.

\section{$\mathrm{H}_{8}$ : Consumer trust in employees will have a positive impact on consumer trust in the company.}

\section{Consequences of Consumer Trust}

As a consequence, consumer trust in the company and employees is expected to positively impact the consumer's loyalty towards the service provider. In this study, a consumer's loyalty is defined as a behavioral intention to maintain a longstanding relationship with the service provider (Sirdeshmukh et al., 2002). As the consumer's loyalty is indicated by an intention to perform a diverse set of behaviors that signal a motivation to maintain a relationship with the focal firm, it has several facets as behavioral intentions; among them are repurchase, less price-sensitivity, allocation of a higher share of the category wallet to the specific service provider, creation of bonds of affection and recommendation of the company (Dwyer et al., 1987; Oliver, 1999; Sirdeshmukh et al., 2002). Special attention has been paid to repurchase intention and positive word-of-mouth communication, which have been used, in recent studies, as dimensions of loyalty (Lam, Shankar, \& Murthy, 2004; Sirdeshmukh, Singh, \& Sabol, 2002; Zeithaml, Berry, \& Parasuraman, 1996). Pursuing the same perspective, these two dimensions are used to measure loyalty in this study.

The logic behind the influence of trust on loyalty is quite simple: trust offers a guarantee as to the consistent and competent performance of the company, assuring that the consumer will continue to gain value from future dealings with the same provider (Sirdeshmukh et al., 2002). In reducing the risk involved in exchanges, trust contributes to giving continuity to the relationship and to creating feelings of loyalty. Thus, the greater the consumer's trust in the company and its employees, the greater the probability of his/her engaging in future dealings and keeping a long-term relationship with it. Likewise, consumers will make comments and recommend companies in which they have a great deal of trust to friends and relatives.

Findings from various studies (Dube \& Maute, 1998; Webster \& Sundaram, 1998) suggest that postcomplaint satisfaction will also positively influence loyalty. The logic of this relationship seems to be based on the theory of social transactions, which suggests that both parties involved in an exchange are motivated to reciprocate the treatment and benefits obtained from this exchange (Thibaut \& Kelly, 1959). This way, complainers will seek to return the company's endeavors to restore their satisfaction either through repurchase intention or positive word-of-mouth communication.

There is a profusion of research on the consequences of the evaluations of satisfaction in the context of complaints. The findings have strongly demonstrated that the level of satisfaction with the complaint handling impacts positively on future repurchase intentions, as well as the real repurchase of complainers (Blodgett et al., 1997; Gilly \& Gelb, 1982; Martin \& Smart, 1994); and, also, word-ofmouth communication (Blodgett et al., 1997; Spreng, Harrell, \& Mackoy, 1995). In addition to the influence of trust and final satisfaction on consumer loyalty, this study proposes the existence of a third antecedent of consumer loyalty: the level of perceived value, which concerns the consumer's evaluation regarding the benefits and costs of maintaining a relationship with the company 
(Sirdeshmukh et al., 2002). The logic here is that, if maintenance costs are high, even when the consumer extracts benefits from the relational exchanges with the company, the relationship will become less attractive, and the evidence of loyalty will decrease - here understood as repurchase and word-of-mouth communication intentions. The findings obtained by Sirdeshmukh et al. (2002) offer empirical evidence for this argument. In their study, perceived value emerged as a significant antecedent of consumer loyalty, irrespective of the service category. Hence, we have the hypotheses:

$\mathrm{H}_{9}$ : Consumer trust in employees will have a positive impact (a) on repurchase intentions and (b) on word-of-mouth communication.

$\mathrm{H}_{10}$ : Consumer trust in the company will have a positive impact (a) on repurchase intention and (b) on word-of-mouth communication.

$\mathrm{H}_{11}$ : Consumer satisfaction with complaint handling will have a positive impact (a) on repurchase intention and (b) on word-of-mouth communication.

$H_{12}$ : The value perceived by the customer will have a positive impact (a) on repurchase intention and (b) on word-of-mouth communication.

Based on the theoretical background and the established hypotheses, Figure 1 illustrates the model to be investigated.

Figure 1: Theoretical Model of the Antecedents and Consequences of Consumer Trust in the Context of Service Recovery

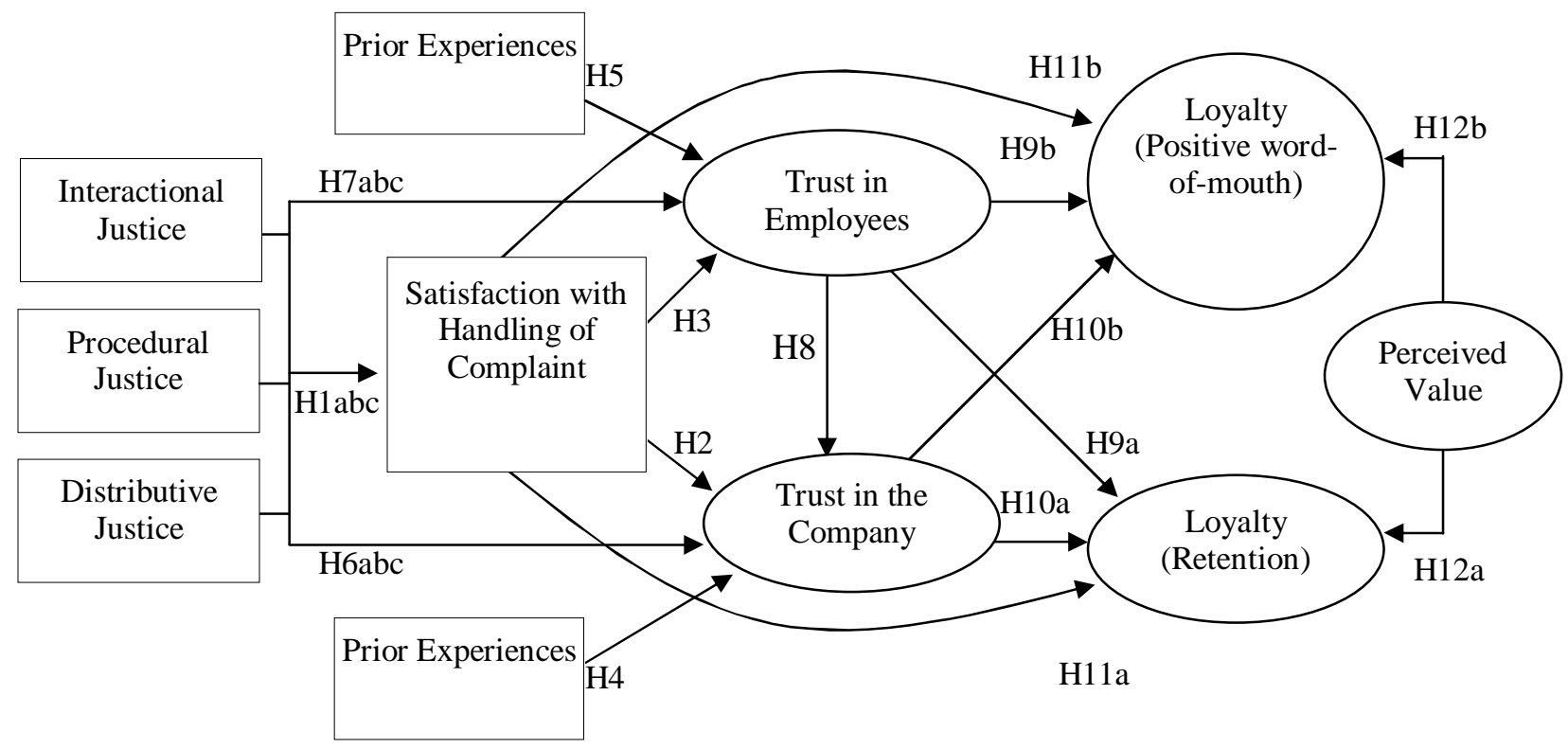

\section{RESEARCH METHOD}

A cross-sectional descriptive study (survey) was carried out with banks and airline company customers that had engaged in complaint processes regarding services provided by companies within these sectors during the past twelve months, and who had already used the company's services in the past.

These services were selected based on Bowen's (1990) typology of service, one of the few empirically-based, comprehensive schemes for service classification. Banks and airline companies were chosen, representing two out of the three types of services found by Bowen. Banks represent 
minimally customized services, having a low-to-moderate level of contact with customers, whereas airline companies provide standardized services, having a moderate-to-high level of contact with customers. Previous studies have chosen banks and hairdressers to represent two different types of service providers (Gwinner, Gremler, \& Bitner, 1998; Jones, Mothersbaugh, \& Beatty, 2000). We nevertheless believe that a greater managerial contribution will be provided through the investigation of the airline sector.

Because these two service industries vary in degree rather than in the absolute sense, a priori predictions, in terms of the differences between the industries, will not be made. Comparisons between the outcomes found concerning the airline companies and banks will increase the generalization of the theoretical model tested.

\section{Sampling and Data Collection Procedures}

We interviewed 405 complainers: 201 from airline companies and 204 from banks. As the focus of this work is on consumers with relatively longstanding relationships with companies, only consumers having had prior experience with the service provider were chosen to be interviewed, concerning both banks and airline companies. Additionally, other criteria added for the sample selection were: airline customers that had traveled three or more times with the company, and whose last trip was with the company in question; bank customers with a relationship of three or more years with the bank in question. The bank should be considered his/her main bank and chosen of his/her free will (not required by an employer). The respondents were approached by interviewers at Salgado Filho International Airport in Porto Alegre. The main advantage of this procedure was the possibility of approaching airline customers without having to obtain client records beforehand. In addition, it was expected that users would willingly respond to the questionnaire at this location, as the majority of them were accustomed to waiting for their flights in the airport lounge. In order for the process to be as random as possible, different schedules (day/hour) were selected, including night-flight and weekend schedules.

It was also believed that air travelers would inevitably make use of banking services, for they tend to have higher purchasing power than the majority of the population. Therefore, both samples - banks and airline complainers - were encountered at the airport.

As a filter question, the interviewer, when approaching potential interviewees, asked whether they had filed a complaint, over the last 12 months, against any airline company or bank institution and whether they had done business with the same company in the past. These data were collected in March, 2005.

\section{Operationalization of the Variables}

The questions were virtually identical for both the investigated industries. Only minor changes were introduced so as to make the questionnaires more suited to the industry under consideration. The measurements applied by Tax et al. (1998) were used - interactional fairness (6 items), procedural fairness (6 items), distributive fairness (4 items), satisfaction with complaint handling (3 items); by Santos and Rossi (2002) - prior experiences; by Sirdeshmukh et al. (2002) - perceived value (4 items), consumer trust in managerial practices (4 items), and trust in employees (4 items); by Oliver and Swan (1989) and Zeithaml et al. (1996) - repurchase intention (3 items); and by Zeithaml et al. (1996) - positive word-of-mouth (3 items). The measures (Appendix), originally from North American studies, were translated into Portuguese through the backtranslation technique (Dillon, Madden, \& Firtle, 1994) and submitted to face validity - we consulted a number of marketing professors and specialists in the two industries to identify problems related to the measures. The questionnaire was modified as requested, and a pre-test, with 15 people who fit the desired profile, was carried out. 


\section{RESULTS}

The findings of this study will be presented as follows: First, a general characterization of the sample will be introduced. Next, the measurement model will be examined using Confirmatory Factorial Analysis [CFA]. The structural model will only be developed after the validity and reliability of the measurements used have been established.

\section{Sample Profile}

The ANOVA test was used to compare the demographic characteristics of the two samples. As no significant difference was found, they were analyzed jointly. The average age of the respondents was 37 and $53 \%$ were male. Forty-five percent $(45 \%)$ of the interviewees had a monthly family income higher than US\$1,800; $31.4 \%$ from US $\$ 900$ to US $\$ 1,800$; and $13.1 \%$ up to US\$ 899 . The majority $(68.6 \%)$ had either obtained a university degree or were undergraduates, and most of the complaints were filed in person (81.7\%). Most frequently, consumers had filed a complaint within the past 6 months (50.4\%). This indicates that a large part of the complaint episodes was relatively recent, thus facilitating the supply of more reliable responses.

Regarding the length of time of the relationship, of the bank complainers, $60 \%$ had been customers for over three years and 53\% worked with more than one bank. Of the airline complainers, $66 \%$ of the interviewees had already used the company services more than three times. Overall, regarding prior contact with companies, $74 \%$ said they had positive or very positive experiences, and only $6.9 \%$ had had negative or very negative experiences. This demonstrates not only that the sample had already had a relationship with the company against which they had filed a complaint, but also that they considered their experiences with the companies prior to the problem to have been positive or very positive.

\section{Discussion of the Measurement Model}

Based on the recommendations of several authors (Churchill, 1999; Hair, Anderson, Tatham, \& Black, 1998), the validity of this model is supported, basically, if: (a) the measurement model adjusts to the data reasonably well, i.e., within the goodness-of-fit indices considered satisfactory; (b) the factorial loadings of the indicators in the corresponding factors are large and significant; (c) indicators of a same construct produce reliability rates higher than 0.70 and extracted variance over 0.50 ; (d) the correlations between indicators (or factors) of a same construct produce convergent evidence of validity; (e) the analysis of correlations between the constructs indicates discriminant validity.

Initially, in order to test the invariance of the measurement model for both services - airline companies and banks - the model was simultaneously estimated for each sector using Multi-Group Structural Equation Modeling. In accordance with the procedures carried out by Sirdeshmukh et al. (2002), all parameters were initially restricted as invariants in both groups, and a totally restricted model was estimated. Subsequently, we used the Lagrange-multiplier test to determine whether the specification of certain parameters as free rather than fixed would lead to a better represented model of the data. This means LM identifies parameters that would contribute to a significant drop in $\chi 2$ if they were to be freely estimated in a subsequent EQS run (Byrne, 1994). In our case, no parameter was indicated when released to provide a significantly better adjustment in the model. This signifies that the measurement model applied can be considered adequate for both types of services investigated. The goodness-of-fit indices for the model are: $\chi^{2}=4988.495, \mathrm{gl}=2581, \chi 2 / \mathrm{gl}=1.93$, NFI $=0.94$, $\mathrm{NNFI}=0.96, \mathrm{CFI}=0.97$ and $\mathrm{RMSEA}=0.08$, and therefore satisfactory.

Proceeding with the analysis of the measurement model, the convergent validity was supported, basically, by the fact that all the items, without exception, presented high and significant factorial coefficients in the constructs that they were supposed to measure (between 0.65 and $0.93 \mathrm{t}$-values over 
10.32). Additionally, there was significant correlation between items associated to the same construct. Therefore, the convergence of measurements, i.e., the existence of a high correlation between the measurements designed to measure the same construct was detected (Churchill, 1999).

Evidence of discriminant validity was found through the correlation levels existing between the constructs. Correlations of over 0.80 would indicate a lack of discriminant validity, i.e., constructs would be measuring the same phenomenon. The highest correlation found was between trust ad loyalty (0.73), which is below 0.80 . thus supporting the discriminant validity among the constructs. Closing the discussion of the measurement model, the measurements applied provided satisfactory levels of reliability and extracted variance. Reliability lay between 0.81 and 0.91 (procedural fairness and distributive fairness, respectively). Extracted variance lay between 0.46 and 0.73 (procedural fairness and word-of-mouth communication, respectively). These indices are in the Appendix, along with factorial loadings. This attests to the internal consistency between the multiple indicators of one variable, highlighting that these are indeed measuring the same construct, and substantially explaining their respective latent constructs.

\section{Test of Hypotheses}

After the assessment of the measures applied, the focus of this study turns back to the theoretical structure developed, which establishes relationships among the proposed theoretical constructs. The set of hypotheses will be investigated, primarily, through the goodness-of-fit indices of the hybrid model and the significance and magnitude of the estimated regression coefficients. Additionally, the determination coefficient was established for each structural equation. This represents the proportion of variance of the dependent variable that is explained by the independent variables.

Prior to this, however, an analysis of the multi-group structural equations was carried out to investigate whether the pooling of the two types of services (banks and airline companies) was appropriate, or whether separate models should be estimated. The greatest advantage of this procedure is to increase the accuracy of the estimated parameters. As with the measurement model, the Lagrange-multiplier test was applied in order to assess the need to allow the established nomological relationships to vary, according to the type of service. Upon being released to vary, no parameter was found to significantly improve the goodness-to-fit of the model. Therefore, it was possible to store the data in a single database.

The findings of the structural model analysis, based on a database of 405 customers, are given in Table 1. The chi-square value is significant. However, knowing that this test is very sensitive to deviances from normality and to samples of over 200, the chi-square value analysis must be made in combination with other adjustment criteria (Hair et al., 1998). When assessed for degrees of freedom, it produces a satisfactory value -2.83 , much lower than the maximum recommended (5). The goodness-of-fit indices - CFI, NFI, NNFI - all well above 0.90 . are considered fairly satisfactory, and the RMSEA of 0.05 is acceptable.

The effect of the perceptions of justice (interactional, procedural and distributive) on satisfaction with complaint management, as proposed in hypotheses $\mathrm{H}_{1 \mathrm{~A}}, \mathrm{H}_{1 \mathrm{~B}}$ e $\mathrm{H}_{1 \mathrm{C}}$ (respectively), were supported by the results obtained. Distributive justice displayed the greatest impact on satisfaction (0.58), whereas the impact of interactional justice, though significant, was the lowest value among the dimensions of justice (0.17). Procedural justice showed a median though significant impact (0.24).

In relation to the impact of the justices on the dimensions of consumer trust on the company $\left(\mathrm{H}_{6 \mathrm{~A}}\right.$, $\mathrm{H}_{6 \mathrm{~B}}$ e $\left.\mathrm{H}_{6 \mathrm{C}}\right)$ and on employees $\left(\mathrm{H}_{7 \mathrm{~A}}, \mathrm{H}_{7 \mathrm{~B}}\right.$ e $\left.\mathrm{H}_{7 \mathrm{C}}\right)$ there was, in a way, an inversion of the previous results, i.e., interactional justice presented a significant and higher-magnitude impact (among the justices) on consumer trust in the company (0.21), and the greatest impact, of all variables analyzed, on consumer trust in employees (0.49), whereas the dimensions of procedural and distributive justices obtained a lesser impact on the trust in the company $(0.12$ and 0.17 , respectively, $\mathrm{P}<0.05)$ and non-significant influence on the trust in employees (.04 and .01). 
Table 1: Estimated Regression Coefficients for the Theoretical Relationships Established in the Model

\begin{tabular}{|c|c|c|}
\hline Model Relationships & Standardized Regression Coefficient ${ }^{\mathrm{a}}$ & Hypotheses \\
\hline \multicolumn{3}{|c|}{ Dependent Variable: Satisfaction with Complaint Handling } \\
\hline Interactional Justice & $\mathbf{0 . 1 7}(2.40)$ & $\mathrm{H}_{1 \mathrm{~A}}-$ Supported \\
\hline Procedural Justice & $0.24(2.72)$ & $\mathrm{H}_{1 \mathrm{~B}}-$ Supported \\
\hline Distributive Justice & $\begin{array}{l}\mathbf{0 . 5 8}(11.70) \\
\mathbf{R}^{2}=\mathbf{0 . 8 9}\end{array}$ & $\mathrm{H}_{1 \mathrm{C}}-$ Supported \\
\hline \multicolumn{3}{|c|}{ Dependent Variable: Consumer Trust in the Company } \\
\hline Satisfaction with Complaint Handling & $0.06(0.59)$ & $\mathrm{H}_{2}$ - Not Supported \\
\hline Experiences prior to the failure & $0.07(1.39)$ & $\mathrm{H}_{4}-\mathrm{Not}$ Supported \\
\hline Consumer trust in employees & $\mathbf{0 . 5 9}(13.09)$ & $\mathrm{H}_{8}-$ Supported \\
\hline Interactional Justice & $0.21(2.61)$ & $\mathrm{H}_{6 \mathrm{~A}}-$ Supported \\
\hline Procedural Justice & $0.12(2.07)$ & $\mathrm{H}_{6 \mathrm{~B}}-$ Supported \\
\hline \multirow[t]{2}{*}{ Distributive Justice } & $0.17(2.09)$ & $\mathrm{H}_{6 \mathrm{C}}-$ Supported \\
\hline & $\mathbf{R}^{2}=\mathbf{0 . 8 2}$ & \\
\hline \multicolumn{3}{|c|}{ Dependent Variable: Consumer trust in employees } \\
\hline Satisfaction with Complaint Handling & $0.14(1.20)$ & $\mathrm{H}_{3}$ - Not Supported \\
\hline Experiences prior to the failure & $0.16(3.37)$ & $\mathrm{H}_{5}-$ Supported \\
\hline Interactional Justice & $0.49(3.30)$ & $\mathrm{H}_{7 \mathrm{~A}}-$ Supported \\
\hline Procedural Justice & $0.04(0.23)$ & $\mathrm{H}_{7 \mathrm{~B}}-\mathrm{Not}$ Supported \\
\hline \multirow[t]{2}{*}{ Distributive Justice } & $0.01(0.07)$ & $\mathrm{H}_{7 \mathrm{C}}-$ Not Supported \\
\hline & $\mathbf{R}^{2}=\mathbf{0 . 4 1}$ & \\
\hline \multicolumn{3}{|c|}{ Dependent Variable: Repurchase Intention } \\
\hline Satisfaction with Complaint Handling & $0.23(3.96)$ & $\mathrm{H}_{11 \mathrm{~A}}-$ Supported \\
\hline Consumer trust in the company & $0.56(5.49)$ & $\mathrm{H}_{10 \mathrm{~A}}$ - Supported \\
\hline Consumer trust in employees & $0.02(0.21)$ & $\mathrm{H}_{9 \mathrm{~A}}-\mathrm{Not}$ Supported \\
\hline \multirow[t]{2}{*}{ Perceived value } & : $0(4.63)$ & $\mathrm{H}_{12 \mathrm{~A}}-$ Supported \\
\hline & $\mathbf{R}^{2}=\mathbf{0 . 6 3}$ & \\
\hline \multicolumn{3}{|c|}{ Dependent variable: Positive word-of-mouth } \\
\hline Satisfaction with Complaint Handling & $0.28(5.53)$ & $\mathrm{H}_{11 \mathrm{~B}}-$ Supported \\
\hline Consumer trust in the company & $0.58(6.65)$ & $\mathrm{H}_{10 \mathrm{~B}}-$ Supported \\
\hline Consumer trust in employees & $0.03(0.42)$ & $\mathrm{H}_{9 \mathrm{~B}}-$ Not Supported \\
\hline \multirow[t]{2}{*}{ Perceived value } & $0.18(4.94)$ & $\mathrm{H}_{12 \mathrm{~B}}-$ Supported \\
\hline & $\mathbf{R}^{2}=\mathbf{0 . 7 2}$ & \\
\hline
\end{tabular}

\section{Goodness-of-fit indices:}

$\begin{array}{lc}\chi 2 \text { (chi-square) } & 2493(\mathrm{p}<.01) \\ \text { GL (Degrees of freedom) } & 878 \\ \text { CFI (Comparative Fit Index) } & 0.97 \\ \text { NFI (Normed Fit Index) } & 0.96 \\ \text { NNFI (NonNormed Fit Index) } & 0.97 \\ \text { RMR (Root Mean Sq. Residual) } & 0.32 \\ \text { RMSEA (Root Mean Sq. Error of Approx.) } & 0.07\end{array}$

${ }^{a}$ t-values(between parentheses). Based on the one-tail test: $t$-values $>1.65=p<0.05$; e t-values $>2.33=p<.01$. Significant Coefficients in bold $=\mathrm{p}<.01$; significant coefficients in italic $=\mathrm{p}<.05$.

These findings demonstrate the great weight placed on the interactional aspect in building trust in the company employees. Moreover, the dissimilar effects of the dimensions of fairness in the constructs of satisfaction and consumer trust demonstrate that companies should treat dimensions of fairness in a combined way, that is, a solicitous and courteous treatment alone will not suffice. For customer satisfaction and the building of trust between the parties, it is necessary to take the three dimensions jointly, taking into account the importance of each dimension in relation to each construct.

The impacts of satisfaction with service recovery on trust in the company and in employees were not significant ( 0.07 and 0.14 , respectively), leading to the rejection of $\mathrm{H}_{2}$ and $\mathrm{H}_{3}$. In order to understand these results better, two alternative models were tested: the first was the original model without the direct effect of the dimensions of justice on the dimensions of trust; the second was the original model without the variable satisfaction. When removing the direct effect of fairness, the impact of satisfaction on the consumer trust in the company and employees was significant $(0.35$ and 0.56 , 
respectively); when removing satisfaction from the model, the effects of the dimensions of fairness on trust remained very much the same $(0.20 .0 .12$ and 0.14 , for interactional, procedural and distributive fairness dimensions, respectively). These results demonstrate that satisfaction does not work, in this case, as a mediator between the dimensions of fairness and trust, because the mediating effect would be diagnosed if, when removing the mediator variable - satisfaction - the effect between fairness dimensions and trusts were significant and, when including satisfaction, this direct effect has decreased significantly, and has even become insignificant (which would indicate a total mediation) (Sirdeshmukh et al., 2002). However, what occurred was precisely the contrary. The effect of satisfaction on dimensions of trust became null when the dimensions of fairness impacted directly on trust (original model). In addition, there was no change in the magnitude of this impact when satisfaction was included in the model. Thus, dimensions of trust are directly impacted by the extent of customer's perception of the company's endeavors regarding service recovery, which would lead to a decrease in the importance of customer satisfaction. This argument, though, is limited, since we must be attentive to the direct influence of satisfaction on customer loyalty - repurchase intention $(0.23)$, confirming $\mathrm{H}_{11 \mathrm{~A}}$, and positive word-of-mouth communication (0.28), supporting $\mathrm{H}_{11 \mathrm{~B}}$, - and, therefore, to the relevance of this construct.

The insignificant impact of experiences prior to the failure on consumer trust in the company (0.07) and the low impact on the trust in employees (0.16) highlight the importance of resolving the failures that occur in a fair way. As this study deals with relational customers, it was expected, as per hypotheses $\mathrm{H}_{4}$ and $\mathrm{H}_{5}$, that the customer experience of the company would have a high impact on trust. However, the findings show that, when failure occurred in delivering a service, the company's response to this failure became critical, to the extent that those customers with a history of satisfactory relationships with the company gave much less importance to this history than to the response to their complaint. It is highlighted that the impact of experiences prior to the failure on consumer trust in the company was not significant, whereas trust in employees had a significant $(\mathrm{p}<.01)$ though low $(0.16)$ impact. An explanation for this difference could be the fact that, when dealing with relational service exchanges, it is likely that the customer's evaluations regarding the prior experiences with the company are closely related to the way employees behaved during the service delivery. In this way, (positive) experiences prior to the failure would have more weight in the evaluation of trust in employees than in the company.

The high impact of consumer trust in employees on trust in the company (0.59) supports the $\mathrm{H}_{8}$ and reveals the companies that the road towards building consumer trust requires building trust between the employee and the customer and, consequently, through a fair interactional treatment in complaint handling.

Despite the absence of hypotheses regarding the reverse impact - consumer trust in the company on the trust in employees - it has been also tested and proven insignificant. Although in their study Sirdeshmukh et al. (2000) found a reciprocal impact between trust in the employees and trust in the company, the present study does not support this effect, having found only a linear influence of trust in employees on trust in the company.

Overall, the antecedents of consumer trust in the company accounted for $82 \%$ of variance, which reinforces the high preceding role of the independent variables included. In relation to trust in employees, the $\mathrm{R}^{2}$ of 0.41 reveals that other variables not included in the model may play a role in the prediction of this construct, as for instance, the level of personal contact between clients and company's employees.

The strong effect of trust in the company on repurchase intention $(0.56)$, associated to $\mathrm{H}_{10 \mathrm{~A}}$, is consistent with the logic that when the level of trust is increased the consumer is supposed to believe that the company will keep acting consistently and competently in the future, thus reducing the risks associated with the purchase of services, and creating the belief that he/she will continue to gain value from future dealings with this service provider. In other words, high consumer trust in the company translates into a greater likelihood of the consumer engaging in future exchanges with the same company and maintaining a long-term relationship with it. Consumer trust in company employees had no direct impact on the repurchase intention, reinforcing the idea that repurchase is the result of consumer trust in the company. As for the other variables, satisfaction $(0.23)$ and perceived value 
(0.20) had reasonable impacts on repurchase intention $\left(\mathrm{H}_{11 \mathrm{~A}}\right.$ and $\mathrm{H}_{12 \mathrm{~A}}$, respectively), though significantly less than trust in the company.

Concerning word-of-mouth communication, the levels of post-complaint satisfaction, trust and value perceived by the consumer seem to have an impact on it, according to hypotheses $\mathrm{H}_{10 \mathrm{~B}}, \mathrm{H}_{11 \mathrm{~B}}$ and $\mathrm{H}_{12 \mathrm{~B}}$. Once again, trust in the company had the highest influence (0.58), while satisfaction had less effect (0.28), and the perceived value, though significant (0.18), had little influence on the consumer predisposition to engage in positive word-of-mouth communication about the company. Again, the influence of trust in employees was not significant, with an $\mathrm{R}^{2}$ of 0.72 , indicating that a significant proportion of the variance of this construct is explained by the three antecedents post-complaint satisfaction, trust and value.

It might be thought that the significant impact of trust in employees on the dimensions of loyalty would be the fruit of its impact on the trust in the company, i.e., the latter would mediate the effect of trust in employees on loyalty. In order to investigate this mediation, a model was tested that excluded the variable deemed to be the mediator - trust in the company - i.e., excluding its relationship with the dimensions of loyalty. In this case, the impact of trust in employees on the repurchase intentions and positive word-of-mouth became significant ( 0.25 and 0.32 , respectively). This fact leads to the belief that trust in employees impacts on repurchase intentions and word-of-mouth communications through the (total) mediation of the trust in the company.

\section{FINAL CONSIDERATIONS}

By and large, the findings indicate that those complaining customers that had experienced a high degree of interactional and distributive fairness tend to repurchase from the company and engage in positive word-of-mouth communication. The procedural fairness dimension had no substantial impact on consumer trust and had a median influence on customer satisfaction. The likely explanation is that customers understand the complexity of dealing with a failure and either accept not receiving an immediate response or not participating in the resolution process, but do wish to receive solicitous treatment (interactional justice) and an appropriate, final response (distributive justice).

This study offers contributions to the knowledge of the service recovery process. The major contribution is that interactional fairness significantly explains a larger percentage of variance of trust in the company and, principally, in employees, than the other dimensions of fairness, suggesting that complainers attribute a great deal of importance to courteous and respectful treatment. In other words, when managing a complaint, offering only tangible results (product replacement, refund, etc.) is not likely to be sufficient in terms of building or re-establishing trust and maintaining the customer's loyalty, although satisfaction with complaint management may be partially achieved. It is noteworthy that, if the direct impact of the dimensions of justice on trust were not considered in this study, the reader might think that the dimensions of distributive and procedural fairness were the most relevant in developing post-complaint satisfaction and, consequently, (through satisfaction mediation) consumer trust. The data, however, indicate the negation of a mediating role for satisfaction between the dimensions of justice and trust, that is, in service recovery, interactional fairness converts itself directly - not via customer satisfaction - into trust, bringing about a decrease in the managerial importance of this construct (satisfaction), and reinforcing the idea that in order to build trust, correct personal treatment is fundamental.

Consumer trust in the company, in turn, has emerged as the most influential factor in repurchase intentions as well as in positive word-of-mouth intentions, followed by satisfaction with complaint management. This strong influence seems to be generated by the fact that in both sectors investigated - banks and airline companies - the perceived risk is great, i.e., if any failure occurs, consequences can be drastic to the customer. Thus, trust in the service provider becomes the key antecedent of repurchase and word-of-mouth communication.

We believe there is enough evidence to support a dual chain of effects: fairness-satisfaction-loyalty 
and fairness-trust in employees-trust in the company-loyalty. In the first chain we have the evaluations of the service recovery impacting the satisfaction with complaint handling that, in turn, impacts the loyalty feelings. In the second chain of effects, fairness evaluations influence trust that, in turn, impacts on loyalty. Comparing both sequences, we can observe that the second one has stronger relationships, especially among interactional fairness-trust in employees-trust in the company-loyalty.

So, after conflict episodes, fairness judgments, not the satisfaction with the complaint handling, play the main role of building or depleting trust and loyalty levels. Such results are possibly not limited to the research settings of this paper, but may represent a marketing phenomenon of wider perspective.

\section{Academic and Managerial Implications}

From the academic perspective, this model examines some relevant but little explored issues in the field of knowledge, namely: (1) trust as a multidimensional construct - trust in employees and trust in company management practices; (2) evaluations of fairness, directly and differently affecting the dimensions of customer trust; (3) the differentiated effect of dimensions of trust on the dimensions of loyalty; (4) the impact of perceived value on consumer loyalty; (5) the testing of the model in two service environments, to a certain extent considered different; (6) the test of the mediating role of satisfaction between the dimensions of justice and trust; (7) the test of the mediating role of trust in the company between trust in employees and the dimensions of loyalty; and (8) loyalty as a two-facet construct, comprising repurchase intentions and company recommendation.

The limited role of satisfaction with complaint handling in the development of trust after conflict episodes is an important theoretical contribution of this study. That does not mean satisfaction is not relevant, but it does lose relevance when we consider the justice evaluations as antecedents of trust. Moreover, satisfaction with complaint handling affects loyalty, but not so strongly as trust does. This moderate impact of satisfaction on loyalty, and the central position of trust, in the context of relational service exchanges, reinforce the change on the emphasis proposed by Garbarino and Johnson (1999), where the consumer's satisfaction, a construct that, for decades, has been seen as a direct precursor of the consumer's behavior after the purchase, gives way to a new construct - consumer's trust - in the role of a guide for actions and future intentions of the consumer to the company with which he has already had a relatively long lasting relationship.

From the managerial perspective, some contributions can be offered. Firstly, the study deals with complaint procedures which, as a rule, are not prioritized and investigated by companies. Additionally, the findings indicate that customers use the responses to their complaints as a basis upon which they establish their attitudes and behavior towards the company, demonstrating that complaints are more than a chance for the company to review its processes and improve them: they are opportunities to develop more solid relationships with customers. Furthermore, from the same perspective, this study supports the idea that the company should attentively observe the interactional aspect - courtesy, sympathy, empathy - in terms of developing relationships. An adequate complaint handling and the consequent trust built between the parties is an efficient way to develop and maintain relationships in the long term. Retailers should train their employees how to listen to the customer, offer an apology, express gratitude for raising the problem and treat the problem in a respectful way. Because of the key role played by interactional fairness in determining consumer trust in the company employees and, consequently, in the company itself, repurchase intention and positive word-of-mouth communication, training programs emphasizing the importance of this dimension may have a significant impact on the success of the business in the long term.

Given the impact of satisfaction with complaint handling on repurchase and word-of-mouth intentions, distributive aspects of the recovery process - the fairness dimension with the strongest influence on satisfaction - require attention from managers as well. They must choose carefully which tangible outcomes to offer to complainers in order to enhance satisfaction. To this end, research into strategies to correct different types of failures should be done. 


\section{Research Limitations and Suggestions}

The contributions made by this study should be seen in the light of the limitations surrounding it. The cross-sectional approach and the non-probalilistic sample, composed of individuals who were at the airport at the moment of the data collection, make it difficult to generalize from the results.

We also examined only clients who had had past relations with the companies. Future research could try to understand how the type of the connection between clients and companies can influence complainers' evaluations of the recovery process, and their consequences. This is a critical piece of information for service organizations, as they may be able to adapt their service recovery strategies to better accommodate these different relationships.

As another limitation, we point out this research was conducted in Brazil, and cultural aspects should be taken into account. For instance, according to Hofstede (1980), we are a collectivistic society. Because we tend to seek long-term relationships, the manner in which consumers are treated during the conflict (interpersonal fairness) would be strongly relevant, and reinforce values such as friendliness, respect and dignity. That may not be the case in other cultures. Furthermore, it seems there is, in Brazil, the occurrence of several failures related to banks and airlines companies, which could generate a sense of distrust in these institutions as a whole. Because of this, trust feelings may enhance loyalty more strongly for our respondents.

Although two service environments considered important for a country's economy were investigated, in order to test the stability of the model developed, it is suggested that the research be applied to other sectors, such as the mobile telephones.

To foster the ability of the companies to deal with clients' grievances, the match of diverse types of failures and their appropriate strategies of recovery could be the focus of an empirical study. It would be useful for managers to understand how to classify failures (e.g., by severity) and which kinds of failures have a stronger influence on satisfaction, trust and loyalty. For instance, failures concerning a disrespectful treatment by an employee could lead to higher dissatisfaction with the complaint management and higher distrust in employees than other types of failures.

Moreover, further studies could explore other antecedents of the dimensions of trust than the ones approached herein and thus increase the predictability of this variable, and could, also, be based on different methods. Longitudinal studies would be especially welcome to examine the sequence of events theorized by the researchers.

\section{REFERENCES}

Barclay, D., \& Smith, J. (1997). The effect of organizational differences and trust on the effectiveness of selling partner relationships. Journal of Marketing, 61(1), 3-21.

Bergen, M., Dutta, S., \& Walker, O. (1992). Agency relationships in marketing: a review of the implications and applications of agency and related theories. Journal of Marketing, 56(3), 1-24.

Berry, L. L. (1996). Retailers with a future. Marketing Management, 5, 38-46.

Berry L. L., \& Leighton J. (2004). Restoring customer confidence. Marketing Health Services, 24(1), 14-27.

Berry, L. L., \& Parasuraman, A. (1991). Marketing services: competing through quality, New York: The Free Press.

Bitner, M., Booms, B., \& Tetreault, M. (1990). The service encounter: diagnosing favorable and unfavorable incidents. Journal of Marketing, 54(1), 71-84. 
Blodgett, J., Hill, D., \& Tax, S. (1997). The effects of distributive, procedural, and interactional justice on complaint behavior. Journal of Retailing, 73(2), 185-210.

Bowen, J. (1990). Development of a taxonomy of services to gain strategic marketing insights. Journal of Academy of Marketing Science, 18(1), 43-49.

Byrne, B. (1994), Structural equation modeling with EQS and EQS/Windows. Thousand Oaks: Sage Publications.

Churchill, G. (1999). Marketing research. Orlando: Fryden Press.

Clemmer, E. (1988). The role of fairness in customer satisfaction with services. Doctoral dissertation. University of Maryland, Maryland, USA.

Clemmer, E., \& Schneider, B. (1996). Fair service. In S. Brown \& D. Bowen (Eds.). Advances in services marketing and management. Greenwich: JAI Press.

Crosby, L., \& Stephens, N. (1987). Effects of relationship on satisfaction, retention, and prices in life insurance industry. Journal of Marketing Research, 24(4), 404-417.

Dillon, W. R., Madden, T. J., \& Firtle, N. H. (1994). Research in a marketing environment. St. Louis: Times Mirror.

Doney, P., \& Cannon, J. P. (1997). An examination of the nature of trust in buyer-seller relationship. Journal of Marketing, 61(2), 35-51.

Dube, L., \& Maute, M. F. (1998). Defensive strategies for managing satisfaction and loyalty in the service industry. Psychology \& Marketing, 15(8), 775-791.

Dwyer, F. R., Schurr, P. H., \& Oh, S. (1987). Developing buyer-seller relationships. Journal of Marketing, 51(2), 11-27.

Folkes, V. S. (1988). Recent attribution research in consumer behavior: a review and new directions. Journal of Consumer Research,14(4), 548-565.

Ganesan, S. (1994). Determinants of long-term orientation in buyer-seller relationships. Journal of Marketing, 58(2), 1-19.

Ganesan, S., \& Hess, R. (1997). Dimensions and levels of trust: implications for commitment to a relationship. Marketing Letters, 8(4), 439-448.

Garbarino, E., \& Johnson, M. (1999). The different roles of satisfaction, trust and commitment for relational and transactional consumers. Journal of Marketing, 63(2), 70-87.

Gilly, M. C., \& Gelb, B. D. (1982). Post-purchase consumer processes and the complaining consumer. Journal of Consumer Research, 9(3), 323-328.

Goodwin, C., \& Ross, I. (1992). Consumer responses to service failures: influence of procedural and interactional fairness perceptions. Journal of Business Research, 25(2), 149-163.

Gwinner, K. P., Gremler, D. D., \& Bitner M. (1998). Relational benefits in services industries: the customer's perspective. Journal of the Academy of Marketing Science, 26(2), 101-114.

Hair, J., Anderson, R. E., Tatham, R., \& Black W. (1998). Multivariate data analysis. New Jersey: Prentice Hall.

Heskett J., Sasser, W., \& Schlesinger, L. (1997). When right makes might. The Journal of Business Strategy, 18(4), 6-8.

Hofstede, G. (1980). Culture's consequences: international differences in work-related values. 
Beverly Hills, CA: Sage.

Jones, T. O., Mothersbaugh, D. L., \& Beatty, S. E. (2000). Switching barriers and repurchase intentions in services. Journal of Retailing, 76(2), 259-274.

Lam, S. Y., Shankar, V., \& Murthy, M. (2004). Costumer value, satisfaction, loyalty, and switching costs: an illustration from a business-to-business service context. Journal of the Academy of Marketing Science, 2(3), 293-311.

Martin, C. L., \& Smart, D. T. (1994). Consumer experiences calling toll-free corporate hotlines. The Journal of Business Communication, 31(3), 195-212.

Mcallister, D. (1995). Affect- and cognition-based trust as foundations for interpe. Academy of Management Journal, 38(1), 24-60.

Messick, D. M., \& Cook, K. S. (1983). Psychological and sociological perspectives on distributive justice: convergent, divergent and parallel lines. In D. Messick \& K. Cook (Eds.). Equity theory: psychological and sociological perspectives. New York: Praeger.

Moorman, C., Deshpande, R., \& Zaltman, G. (1993). Factors affecting trust in market research relationships. Journal of Marketing, 57(1), 81-102.

Morgan, R. M., \& Hunt, S. D. (1994). The commitment-trust theory of relationship marketing. Journal of Marketing, 58(3), 20-38.

Nooteboom, B., Berger, H., \& Noorderhaven, N. (1997). Effects of trust and governance on relational risk. Academy of Management Journal, 40(2), 308-338.

Oliver, R. L. (1999). Whence costumer loyalty? Journal of Marketing, 63, 33-44.

Oliver, R. L., \& Swan, J. (1989). Consumer perceptions of interpersonal equity in transactions: a field survey approach. Journal of Marketing, 53(2), 21-35.

Rousseau, F., Sitkin, S., Burt, R., \& Camerer, C. (1998). Not so different after all: a cross-discipline view of trust. The Academy of Management Review, 23(4), 393-404.

Ruyter, K., \& Wetzels, M. (1999). Commitment in auditor relationships: antecedents and consequences. Accounting, Organizations and Society, 24(1), 57-76.

Santos, C. P., \& Rossi, C. A. V. (2002, May). The impact of complaint handling on consumer's trust and loyalty in the context of relational services exchanges. Proceedings of the European Marketing Academy Conference, Braga, Portugal, 31.

Singh, J., \& Sirdeshmukh, D. (2000). Agency and trust mechanisms in satisfaction and loyalty judgements. Academy of Marketing Science Journal, 28(1), 150-168.

Sirdeshmukh, D., Singh, J., \& Sabol, B. (2002). Consumer trust, value and loyalty in relational exchanges. Journal of Marketing, 66(1), 15-37.

Smith, A. K, Bolton, R. N., \& Wagner, J. (1999). A model of customer satisfaction with service encounter involving failure and recovery. Journal of Marketing Research, 36, 356-372.

Spreng, R. A., Harrell, G. D., \& Mackoy, R. D. (1995). Service recovery: impact on satisfaction and intentions. Journal of Services Marketing, 9(1), 15-23.

Tax, S. S., Brown, S. W., \& Chandrashekaran, M. (1998). Customer evaluations of service complaint experiences: implications for relationship marketing. Journal of Marketing, 62(2), 60-76.

Thibaut, J., \& Kelley, H. H. (1959). The social psychology of groups. New York: Wiley. 
Thibaut, J., \& Walker, L. (1975). Procedural justice: a psychological analysis. Hillsdale: Lawrence Erlbaum.

Webster, C., \& Sundaram, D. S. (1998). Service consumption criticality in failure recovery. Journal of Business Research, 41(2), 153-159.

Westbrook, R. A. (1987). Product/consumption-based affective responses and postpurchase processes. Journal of Marketing Research, 24(3), 258-270.

Zeithaml, V. A., Berry, L. L., \& Parasuraman, A. (1996). The behavioral consequences of service quality. Journal of Marketing, 60(2), 31-46. 


\section{APPENDIX: Operational Measures Used for Constructs}

\begin{tabular}{|c|c|c|c|c|}
\hline & $\begin{array}{l}\text { Coefficient } \\
\text { Alpha }\end{array}$ & $\begin{array}{l}\text { Factor } \\
\text { Loadings }\end{array}$ & $\begin{array}{l}\text { Composite } \\
\text { Reliability }\end{array}$ & $\begin{array}{l}\text { Variance } \\
\text { Extracted }\end{array}$ \\
\hline Interpersonal Fairness $^{\mathrm{a}}$ & 0.92 & & 0.87 & 0.53 \\
\hline 1. They communicated honestly with me. & & 0.66 & & \\
\hline 2. The people were courteous to me. & & 0.65 & & \\
\hline $\begin{array}{l}\text { 3. I was given a reasonable explanation as to why the original problem } \\
\text { occurred. }\end{array}$ & & 0.62 & & \\
\hline 4. They seemed very concerned about my problem. & & 0.63 & & \\
\hline 5. They tried hard to resolve the problem. & & 0.61 & & \\
\hline 6. The people apologized for the problem. & & 0.59 & & \\
\hline Procedural Fairness $^{\mathbf{a}}$ & 0.87 & & 0.81 & 0.46 \\
\hline 1. I got a chance to tell them the details of my problem. & & 0.67 & & \\
\hline 2. I had some control over the result I received from the complaint. & & 0.60 & & \\
\hline 3. They responded quickly to my complaint. & & 0.64 & & \\
\hline 4. They adapted their complaint handling procedures to satisfy my needs. & & 0.62 & & \\
\hline 5. They made it easy for me to voice my complaint. & & 0.76 & & \\
\hline 6. They assumed responsibility for the problem. & & 0.68 & & \\
\hline Distributive Fairness $^{a}$ & 0.97 & & 0.91 & 0.73 \\
\hline 1. The result of the complaint was right. & & 0.84 & & \\
\hline 2. In resolving the complaint, the company gave me what I needed. & & 0.86 & & \\
\hline 3. The result of the complaint was what I expected. & & 0.88 & & \\
\hline 4. I received what I required. & & 0.85 & & \\
\hline Satisfaction with the Recovery Service ${ }^{a}$ & 0.96 & & 0.89 & 0.73 \\
\hline 1. I was happy with how the organization handled my complaint. & & 0.73 & & \\
\hline 2. I was pleased with the manner in which the complaint was dealt with. & & 0.77 & & \\
\hline 3. Overall, I was not satisfied with the way the complaint was handled. & & 0.77 & & \\
\hline Consumer Trust in Management Practices and Polices ${ }^{a}$ & 0.95 & & 0.88 & 0.65 \\
\hline \multicolumn{5}{|l|}{ I feel that this company is: } \\
\hline 1. Very Undependable/Very Dependable & & 0.62 & & \\
\hline 2. Very Incompetent/Very Competent & & 0.65 & & \\
\hline 3. Of Very Low Integrity/Of Very High Integrity & & 0.76 & & \\
\hline 4. Very Unresponsive to Customers/Very Responsive to Customers & & 0.74 & & \\
\hline
\end{tabular}

\footnotetext{
${ }^{\text {a }}$ Measured using a five-point likert item anchored by Strongly Disagree / Strongly Agree.
} 


\section{(conclusion)}

\begin{tabular}{|c|c|c|c|c|}
\hline & $\begin{array}{l}\text { Coefficient } \\
\text { Alpha }\end{array}$ & $\begin{array}{l}\text { Factor } \\
\text { Loadings }\end{array}$ & $\begin{array}{l}\text { Composite } \\
\text { Reliability }\end{array}$ & $\begin{array}{l}\text { Variance } \\
\text { Extracted }\end{array}$ \\
\hline Consumer Trust in Frontline Employees ${ }^{b}$ & 0.95 & & 0.90 & 0.69 \\
\hline \multicolumn{5}{|l|}{ I feel that the employees of this company are: } \\
\hline 1. Very Undependable/Very Dependable & & 0.83 & & \\
\hline 2. Very Incompetent/Very Competent & & 0.82 & & \\
\hline 3. Of Very Low Integrity/Of Very High Integrity & & 0.85 & & \\
\hline 4. Very Unresponsive to Customers/Very Responsive to Customers & & 0.76 & & \\
\hline Perceived Value $^{b}$ & 0.89 & & 0.85 & 0.58 \\
\hline \multicolumn{5}{|l|}{$\begin{array}{l}\text { Please tell us your evaluation of the service provider on the following } \\
\text { factors: }\end{array}$} \\
\hline $\begin{array}{l}\text { 1. The prices you pay for the service are a: Very Poor Deal/Very Good } \\
\text { Deal }\end{array}$ & & 0.70 & & \\
\hline $\begin{array}{l}\text { 2. The time you spent in order to use the service is: Highly } \\
\text { Reasonable/Highly Unreasonable }\end{array}$ & & 0.81 & & \\
\hline $\begin{array}{l}\text { 3. The effort involved in dealing with the company is: Not At All } \\
\text { Worthwhile/Very Worthwhile }\end{array}$ & & 0.76 & & \\
\hline $\begin{array}{l}\text { 4. Given the time, effort, and cost involved in using the services of the } \\
\text { company, how would rate it? Extremely Poor Value/Extremely Good } \\
\text { Value }\end{array}$ & & 0.79 & & \\
\hline Loyalty - Word-of-mouth ${ }^{c}$ & 0.97 & & 0.89 & 0.93 \\
\hline \multicolumn{5}{|l|}{ How likely are you to: } \\
\hline 2. Recommend this company to friends, neighbors and relatives? & & 0.87 & & \\
\hline 4. Say positive things about this company to other people? & & 0.89 & & \\
\hline $\begin{array}{l}\text { 6. Encourage your friends and family to make business with this } \\
\text { company? }\end{array}$ & & 0.71 & & \\
\hline Loyalty - Retention ${ }^{\mathrm{c}}$ Do/will you & 0.94 & & 0.88 & 0.64 \\
\hline 1. Do most of your business with this company? & & 0.77 & & \\
\hline $\begin{array}{l}\text { 3. Deal with this company the very next time you need that kind of } \\
\text { service? }\end{array}$ & & 0.73 & & \\
\hline 5. Do more business with this company in the future? & & 0.70 & & \\
\hline 7. Consider this company your first choice to buy that kind of service? & & 0.75 & & \\
\hline
\end{tabular}

\footnotetext{
${ }^{\mathrm{b}}$ Measured using a five-point Semantic Differential.

${ }^{\mathrm{c}}$ Measured using a five-point likert items anchored by Very unlikely / Very likely.
} 